\title{
MENGUKUR PRESTASI BELAJAR PENDIDIKAN AGAMA ISLAM SISWA SMP DALAM PERSPEKTIF GENDER
}

\author{
Arif Rahman Hakim, Lathifatul Izzah \\ Universitas Alama Ata Yogyakarta \\ lathifatul.izzah@almaata.ac.id
}

\section{ABSTRAK}

This study aims to prove that gender does not affect the learning achievement of Islamic education and character of junior high school students. The construct in society is that men are superior to women. Men are smarter than women. The problem solving in this research uses quantitative research with comparative analysis. In this study, the authors used data collection techniques in the form of conventionalized results of Mid-Semester Assessment (PTS) and Final Semester Assessment (PAS). The results showed the mean score of male students in the Islamic Religious Education subject was 81.51 with a standard deviation of 6.863 with a total range of 27. The lowest score for male students was 68 and the highest score was 95 . The majority of male students scored category is quite good (C) or a value of $75-83$, that is, there are 25 students or $47.2 \%$ of the 53 male students. The average achievement score of female students in the subject of Islamic Religious Education has an average of 85.57 with a standard deviation of 7.324, a total range of 28, the lowest score is 71 and the highest score is 99. The majority of students scored quite well, between scores of 75-83, namely as many as 20 students or $37.7 \%$ of 53 female students. In the independent $t$ test it is known that the sig (2 tailed) value of 0.29 and $>0.05$, from these results it shows that Ho is accepted and Ha is rejected, meaning that there is no positive and significant difference between male and female students to get achievement. learn Islamic religious education. 
Keywords: Learning achievement of Islamic Religious Education, Gender Perspective, male students, female students

\section{A. PENDAHULUAN}

Sistem Pendidikan Nasional dalam pasal 5 ayat 1 Undang-undang nomer 20 Tahun 2003 menyatakan, setiap warga negara, laki-laki dan perempuan mempunyai hak yang sama untuk mendapatkan pendidikan yang bermutu. Kesempatan memperoleh pendidikan tidak membedakan jenis kelamin, status sosial, ekonomi, agama, dan lokasi geografis. Kebijakan pemerataan dan perluasan kesempatan pendidikan memberi kesempatan pada setiap orang untuk mengakses pendidikan pada semua jenis, jenjang, dan jalur pendidikan. Dasar pemerataan pendidikan bukan semata-mata untuk pemerataan saja, tetapi pemerataan untuk mencapai keadilan dan kesejahteraan ${ }^{1}$

Dalam kitab Musnad Ibnu Hanifah, sebuah hadits yang diriwayatkan oleh Abdullah bin Masud Rasulullah bersabda "menuntut ilmu itu wajib setiap muslim (laki-laki dan perempuan)". ${ }^{2}$ Manusia sebagai makhluk Tuhan telah diberi kemampuan-kemampuan dasar yang sifatnya rohaniyah dan jasmaniyah, yaitu fitrah (potensi). Setiap orang harus mengembangkan fitrah atau potensi yang ada di dalam dirinya. Pengembangan fitrah atau potensi yang tepat melalui pebelajaran atau dengan pendidikan, baik formal, informal, maupun non-formal. ${ }^{3}$

Sekolah Menengah Pertama (SMP) merupakan lingkungan belajar bagi anak usia peralihan dari masa kanak-kanak ke masa remaja pada jenjang pendidikan formal. Sifat-sifat remaja sebagian sudah tidak menunjukan kanakkanaknya, tetapi juga belum menunjukan sifat-sifat orang dewasa. Pada tahapan ini siswa berada pada periode peralihan yang harus meninggalkan segala sesuatu yang sifatnya kekanak-kanakan dan mempelajari pola prilaku dan sikap baru untuk menggantikan prilaku dan sikap kekanak-kanakannya. ${ }^{4}$

${ }^{1}$ Evi Muafiah,"Pendidikan Islam Berperspektif Gender" Jurnal Tadris, Vol. 5 No. 2, 2010, 194196.

2 Kitab Musnad Abu Hanifah, Jawamiu al Kalim 4.5, hlm 160

3 Data dari Indonesian Educational Statistic Brief memuat bahwa pada tingkat SD (Sekolah Dasar) tercatat secara umum lebih banyak laki-laki bersekolah pada tahun ajaran 1999/2000 dengan rerata perbandingan $51,68 \%$ laki-laki dan $48,32 \%$ perempuan. Sedang tingkat SMP 51,40\% laki-laki dan 48,60\% perempuan, tingka SMA 56,42\% laki-laki dan 43,58\% perempuan dan untuk Perguruan Tinggi 56,42\% laki-laki dan 43,58\% perempuan. Sebagaimana dikutip Gadis Arivia, Feminisme; Sebuah Kata Hati (Jakarta: Penerbit Buku Kompas, 2006), hlm. 40

4 Rohma Dwi Yuniarti, "Pengaruh Sikap dan Gender Terhadap Prestasi Belajar Bahasa 
Dalam pembelajaran setiap anak laki-laki dan perempuan adalah unik dan berkembang dengan tahapan yang berbeda-beda. Pertumbuhan fisik semasa tumbuh kembang, sejak dilahirkan hingga memasuki usia remaja pada dasarnya anak laik-laki dan perempuan memiliki pertumbuhan yang relatif setara dalam berat badan. Perbedaan pertumbuhan antara laki-laki dan perempuan dalam pertumbuhan tidak terlalu signifikan, hingga nanti memasuki masa akhir sekolah dasar. Anak perempuan mulai lebih tinggi dan lebih cepat pertumbuhannya, sementara anak laki-laki akan tumbuh dengan cepat, terutama tinggi badannya setelah beberapa tahun setelahnya.

Dalam keterampilan verbal faktor hormonal sangat mempengaruhi fungsi otak, sehingga membedakan reaksi anak laki-laki dan perempuan terhadap keterampilan verbal. Anak laki-laki cenderung lebih lambat berbicara dan memiliki kosa kata yang lebih sedikit daripada anak perempuan. Anak perempuan cenderung lebih mahir membaca tanda-tanda non-verbal, seperti intonasi dan ekspresi, sehingga secara umum anak perempuan lebih terampil berkomunikasi, terutama yang melibatkan emosi dan penguatan kata-kata.5 "Perbedaan laki-laki dan perempuan hampir ada di setiap lini kehidupan baik pada pendidikan, sosial, politik, dan sebagainya. Berdasarkan penelitian yang dilakukan oleh Meighand (1981) dalam Rohma Dwi menunjukkan data tentang perolehan nilai A pada anak laki-laki dan perempuan di Amerika Serikat. Perbandingan perolehan nilai A anak laki-laki dan perempuan pada mata pelajaran fisika 6:1, Matematika 4:1, Kimia 3:1, Biologi 9:8, Mengambar 2:1, Bahasa 1:2. Secara lebih spesifik studi ini berupaya melihat bahwa jenis kelamin mempengaruhi perolehan prestasi belajar", ${ }^{6}$ sehingga konstruksi di masyarakat, dalam beberapa hal laki-laki lebih cerdas dan lebih pintar daripada perempuan.

Tulisan ini merupakan hasil penelitian yang dilakukan di SMP Negeri 14 Yogyakarta kelas VIII dengan jumlah siswa secara keseluruhan 53 siswa. Dari kondisi siswa yang ada antara laki-laki dan perempuan memiliki prestasi tersendiri pada mata pelajaran tertentu. Dalam pendidikan Agama Islam berda-

Indonesia Pada Siswa SMP Negeri Kelas VII Di Kecamatan Sleman Yogyakarta”, Skripsi, (Yogyakarta: Universitas Negri Yogyakarta, 2013). Hlm. 1.

5 Rini Sekar Tini, "Perbedaan Pertumbuhan Laki-laki dan Perempuan", diakses dari https://www.parenthingclub.co.id/smart-stories/perbedaan-pertumbuhan-anaklaki-laki-dan-perempuan pada hari selasa, 13 oktober 2018, pukul 20:22 WIB. Lihat juga Myrtati D. Artaria, Perbedaan antara Laki-laki dan Perempuan: Penelitian Antropometris pada Anak-Anak Umur 6-19 Tahun, Jurnal Masyarakat Kebudayaan Dan Politik, Vol. 2, No.4: 343-349

6 Rohma Dwi Yuniarti, “Pengaruh Sikap dan..., hlm. 13 
sarkan pelaksanaan Praktik Pengalaman Lapangan (PPL) pada bulan Agustus - September 2018 di SMP Negeri 14 Yogyakarta menemukan hasil di kelas VIII A antara siswa laki-laki dan siswa perempuan bahwa siswa perempuan lebih unggul dalam komunikasi, lebih aktif dan memiliki nilai harian rata-rata 78 : 75 dalam mata pelajaran Pendidikan Agama Islam. Berangkat dari kasus tersebut, maka diperlukan studi lanjut apakah memang benar perempuan lebih unggul daripada laki-laki dalam pembelajaran pendidikan Agama Islam? Apakah ada perbedaan prestasi belajar Pendidikan Agama Islam antara siswa laki-laki dan perempuan yang terjadi di kelas VIII SMP Negeri 14 Yogyakarta? Dalam tulisan pelajaran Pendidikan Agama Islam yang dimaksud adalah mata pelajaran Pendidikan Agama Islam dan Budi Pekerti.

Uraian tersebut menggiring penulis untuk membuktikan bahwa jenis kelamin tidak mempengaruhi prestasi belajar Pendidikan Agama Islam siswa usia SMP. Konstruk di masyarakat dikatakan bahwa laki-laki lebih cerdas daripada perempuan. Otak laki-laki ada 99 dan otak perempuan 1. Pembuktian ini dilakukan dengan memakai metode komparatif kuantitatif. Penelitian komparatif merupakan penelitian yang digunakan untuk membandingkan persamaan dan perbedaan dua atau lebih fakta-fakta dan sifat-sifat objek yang diteliti berdasarkan kerangka pemikiran tertentu. ${ }^{7}$ Metode komparatif dalam penelitian ini diterapkan untuk melihat perbandingan hasil prestasi belajar pendidikan agama Islam antara siswa laki-laki dan perempuan dalam mata pelajaran pendidikan Agama Islam dan Budi Pekerti kelas VIII di SMP Negeri 14 Yogyakarta, tahun ajaran 2018-2019.

\section{B. KONSEP, ASPEK, DAN FAKTOR MEMPENGARUHI PRESTASI BELAJAR}

Prestasi belajar berasal dari dua kata, prestasi dan belajar. Prestasi berasal dari istilah prestatie (bahasa Belanda), yaitu hasil dari suatu kegiatan yang sudah dilakukan dan diciptakan oleh individu atau kelompok. Singkat kata, prestasi adalah hasil usaha yang dicapai atau sesuatu yang dihasilkan. Sedang belajar berarti proses usaha yang dilakukan seseorang untuk memperoleh suatu perubahan tingkah laku yang baru secara keseluruhan sebagai hasil dari pengalaman individu dalam berinteraksi dengan lingkungannya, sehingga menghasilkan perubahan-perubahan. ${ }^{8}$ Perubahan tersebut tidak saja berupa

\footnotetext{
7 Nana Syaodih Sukmadinata, Metode Penelitian Pendidikan, (Bandung: Remaja Rosdakarya, 2011), hlm. 58.

8 Moh Zaiful Rasyid dkk., Prestasi Belajar, (Malang: Literasi Nusantara, 2019), hal. 5 - 8
} 
penambahan ilmu pengetahuan, tetapi juga berupa kecakapan, ketrampilan, sikap, perilaku, harga diri, minat, watak, dan penyesuaian diri. Zainal Arifin dalam Moh Zaiful Rasyid dkk. mengungkapkan prestasi belajar (achievement) berbeda dengan hasil belajar (learning outcome). Umumnya, prestasi belajar berkaitan dengan aspek pengetahuan, sedang hasil belajar mencakup pembentukan watak siswa.?

Lawrence dan Vimala dalam Rita Eka Izzaty dkk menganggap prsetasi belajar sebagai ukuran pengetahuan yang didapat dari pendidikan formal dan diwujudkan melalui test. Kpolovie dkk lebih lanjut menjelaskan bahwa prestasi belajar merupakan keamampuan siswa dalam belajar untuk mengingat fakta yang berupa pengetahuan, kemudian dikomunikasikan secara lisan dan tulisan dalam ujian. Prestasi belajar mereflesikan penguasaan pada mata pelajaran yang ditunjukkan melalui angka atau nilai oleh guru. ${ }^{10}$ Syaiful Bahri Djamarah dalam Moh Ziful Rasyid, dkk. menjelaskan prestasi belajar sebagai hasil yang dicapai oleh peserta didik selama proses pembelajaran dalam kurun waktu tertentu, yang diwujudkan dalam bentuk angka, huruf, simbol atau kalimat. Hasil ketercapaian pembelajaran siwa tersebut meliputi beberapa aspek, kognitif, afektif, dan psikomotorik. ${ }^{11}$

Aspek kognitif merupakan aspek pengukuran yang tertinggi dalam pencapaian prestasi belajar yang dilakukan melalui tes lisan dan tulisan. ${ }^{12}$ Aspek kognitif meliputi pengetahuan, pemahaman, penerapan, analisis, sintesis, dan evaluasi. Aspek afektif merupakan aspek pengukuran yang meliputi watak perilaku, misalnya perasaan, minat, sikap, emosi, atau nilai yang menentukan keberhasilan belajar seseorang. Terakhir aspek psikomotorik, merupakan aspek yang berhubungan dengan olah gerak yang berhubungan dengan otototot syaraf, misalnya lari, langkah, menggabar, berbicara, bongkar pasang peralatan, dan sebagainya. ${ }^{13}$

Pencapaian prestasi belajar baik dalam aspek kognitif, afektif, dan psikomotorik dapat dipengaruhi oleh beberapa faktor, misalnya faktor jasmani, kecerdasan, bakat, potensi, sikap, kebiasaan, minat, kebutuhan, motivasi,

\footnotetext{
9 Ibid., hal. 6

${ }^{10}$ Rita Eka Izzaty, dkk, "Prediktor Prestasi Belajar Siswa Kelas 1 Sekolah Dasar", Jurnal Psikologi, Volume 44, Nomor 2, 2017, hal. 154.

${ }^{11}$ Ibid., hal. 8

${ }^{12}$ Muhibbin Syah, Muhibbin Syah, Psikologi Pendidikan Dengan Pendekatan Baru, Edisi Revisi, (Bandung: PT Rajagrafindo Persada, 2008), hlm

${ }^{13}$ Ahmad Syafi'i dkk, "Studi Tentang Prestasi Belajar Siswa Dalam Berbagai Aspek Dan Faktor Yang Mempengaruhi”, Jurnal Komunikasi Pendidikan, Vol 2., No 2 Juli 2018, hal. 119 -120.
} 
emosi, dan kematangan. Faktor-faktor tersebut dimasukkan faktor internal. Selain internal ada faktor eksternal yang meliputi lingkungan keluarga, sekolah, masyarakat, kelompok, adat istiadat, ilmu pengetahuan, teknologi, kesenian, fasilitas yang ada di rumah dan sekolah, dan iklim. ${ }^{14}$

\section{CARA MENGUKUR PRESTASI BELAJAR}

Tes prestasi (achiement test) adalah tes yang digunakan untuk mengukur pencapaian seorang setelah mempelajari sesuatu (Arikunto 2006: 194) tes prestasi ini dapat dilakukan di akhir pembelajaran dan tes yang diujikan dari segala sesuatu yang diajarkan. Pada umumnya tes digunakan untuk mengukur tingkat keberhasilan peserta didik dalam mencapai tujuan tertentu dalam kegiatan pembelajaran. "Tingkat keberhasilan peserta didik dapat dipahami sebagai sesuatu kegiatan pembelajaran atau sebelum mengikuti kegiatan pembelajaran tersebut."

Jenis test yang dapat dijadikan tolak ukur prestasi belajar peserta didik adalah sebagai berikut: pertama tes kemampuan awal, yaitu tes yang dilakukan sebelum peserta didik mengalami proses pembelajaran. Ada tiga jenis tes kemampuan awal yaitu pretes, tes persyarat, dan tes penempatan. Tes kemampuan ini dapat dilakukan sebelum peserta didik memulai sesuatu kegiatan pembelajaran atau tes masuk di lembaga pendidikan. Kedua tes diagnosis, tes ini dilakukan sebelum atau selama berlangsungnya sesuatu pembelajaran. Ndikator, dan bahan ajar tertentu yang masih menyulitkan peserta didik. Dari tes ini dapat diketahui kelemahan peserta didik sehingga dapat dibuat suatu kebijakan dalam kegiatan pembelajaran. Ketiga tes formatif. Tes formatif dilakukan selama kegiatan pembelajaran masih berlangsung pada setiap akhir beberapa kompetisi dasar atau satuan pembahasan. Tes ini sangat berguna bagi pendidik maupun peserta didik karena dengan tes ini pendidik maupun peserta didik dapat dengan langsung mengetahui kelebihan maupun kekurangan peserta didik dalam memahami konsep maupun aplikasi kompetisi dasar yang diajarkan. Keempat tes sumatif. Tes sumatif dilakukan stelah selesainya seluruh kegiatan pembelarajan atau seluruh program yang direncakan. Tes ini biasanya dilakukan di akhir semester yang disebut ulangan umum. Adapun kompetensi yang telah diajarkan selama satu semester. Pada umumnya tes ini digunakan untuk menentukan naik tidaknya atau lulus peserta didik. ${ }^{15}$

${ }^{14}$ Ibid., hal 121.

15 Rohma Dwi Yuniarti, "Pengaruh Sikap Dan Gender Terhadap Prestasi Belajar Bahasa Indonesia Pada Siswa Smp Negri Kelas Vii Di Kecamatan Sleman Yogyakarta. Fakultas Bahasa 


\section{PENDIDIKAN AGAMA ISLAM}

Pendidikan Agama Islam (PAI) yang dimaksud dalam tulisan ini adalah mata pelajaran Pendidikan Agama Islam dan Budi Pekerti. Mata pelajaran ini memberikan pengetahuan dan keterampilan serta membentuk sikap, dan kepribadian peserta didik dalam mengamalkan ajaran Agama Islam. Mata Pelajaran Pendidikan Agama Islam dan Budi Pekerti dilaksanakan melalui mata pelajaran pada semua jenjang pendidikan, yang pengalamannya dapat dikembangkan dalam berbagai kegiatan baik bersifat kokurikuler maupun ekstrakurikuler. Pendidikan Agama Islam dan Budi Pekerti adalah pendidikan yang berlandaskan pada aqidah yang berisi tentang keesaan Allah SWT sebagai sumber utama nilai-nilai kehidupan bagi manusia dan alam semesta. Sumber lainnya adalah akhlak yang merupakan manifestasi dari aqidah, yang sekaligus merupakan landasan pengembangan nilai-nilai karakter bangsa Indonesia. Dengan demikian, mata pelajaran Pendidikan Agama Islam ditujukan untuk dapat menserasikan, menselaraskan dan menyeimbangkan antar iman, islam, dan ihsan yang diwujudkan dalam ruang lingkup sebagai berikut: (1) Hubungan manusia dengan Allah SWT, Membentuk manusia Indonesia yang beriman dan bertaqwa kepada Allah SWT serta berakhlakk mulia dan berbudi pekerti luhur, (2) hubungan manusia dengan diri sendiri, yang meliputi menghargai, menghormati dan mengembangkan potensi diri yang berlandaskan pada nilai-nilai keimanan dan ketaqwaan, dan (3) hubungan manusia dengan sesama.

Menjaga kedamaian dan kerukunan hubungan inter dan umat beragama serta menumbuh kembangkan akhlak mulia dan budi pekerti luhur. (4) Hubungan manusia dengan lingkungan alam, penyesuaian mental keislaman terhadap lingkungan fisik dan sosial. ${ }^{16}$ Dalam pendidikan agama Islam juga dimasukkan unsur-unsur budi pekerti, yang memiliki makna sama dengan pendidikan moral, pendidikan karakter, pendidikan akhlak dan pendidikan nilai. Secara umum ruang lingkup pendidikan Budi Pekerti adalah penanaman dan pengembangan nilai-nilai budi pekerti luhur pada siswa. Diantara nilainilai yang perlu ditanamkan adalah sopan santun, disiplin, beriman, bertaqwa,

dan Seni, Universitas Negri Yogyakarta”, Skripsi, (Yogyakarta: Universitas Negeri Yogyakarta, 2013), hal. 24-26.

${ }^{16}$ Fahrudin, Hasan Asari, Siti Halimah, Implementasi Kurikulum 2013 Pendidikan Agama Islam Dan Budi Pekerti Dalam Menanamkan Akhlakul Karimah Siswa, Edu Religia, Vol. 1 No. 4 Oktober-Desember 2017, 516-531 
bertanggung jawab, jujur, dan lain sebaginya. ${ }^{17}$

\section{E. KOMPETENSI MEMPELAJARI PENDIDIKAN AGAMA ISLAM DAN BUDI PEKERTI DI SEKOLAH MENENGGAH PERTAMA}

Kompetensi yang diharapkan setelah siswa mempelajari Pendidikan Agama Islam dan Budi Pekerti di Sekolah Menengah Pertamayang dapat dilihat sebagai berikut: (1) Al-Qur'an, berkaitan dengan pembelajaran al Qur'an siswa diharapkan mampu membaca, menghafal, menghayati, dan menyajikan keterkaitan antara sikap dengan nilai-nilai yang terkandung di dalam ayat-ayat pilihan, (2) Aqidah, berkaitan dengan pembelajaran Aqidah siswa diharapkan mampu meyakini, menghayati, memahami dan menyajikan contoh perilaku yang mencerminkan ajaran tentang rukun iman, (3) Akhlak, berkaitan dengan Akhlak siswa diharapkan mampu meyakini, menghayati, memahami dan menyajikan contoh perilaku yang mencerminkan ajaran tentang rukun iman, (4) Fiqih, berkaitan dengan Fiqih siswa diharapkan mampu menjalankan, menghayati, memahami dan menyajikan serta mempraktikan tata cara bersuci dari hadas kecil dan hadas besar, shalat wajib berjamaah, shalat jum'at, shalat sunah berjamaah dan mufarid, sujud syukur, sujud tilawah, sujud sahwi, puasa wajib dan sunnah, makanan dan minuman yang halal dan haram, zakat, ibadah haji dan umrah, penyembelihan hewan, qurban dan aqiqah sesuai dengan ketentuan syariat Islam, dan (5) Sejarah Peradaban Islam (SPI), berkaitan dengan SPI siswa diharapkan mampu menghayati, meneladani, memahami, dan menyajikan rangkaian sejarah perjuangan Nabi Muhammad SAW. Periode Makkah Mdinah, al-Khulafah al-Rsyidin, Bani Umayah Abbasiyah, Berkembangnya dan tradisi Islam di Nusantara.

\section{F. RUANG LINGKUP DAN CONTOH MATERI AJAR PENDIDIKAN AGAMA ISLAM DAN BUDI PEKERTI}

Adapun ruang lingkup pendidikan Agama Islam dan Budi Pekerti pada sekolah Menngah Pertama/Mdrasah Tsanawiyah meliputi: Al-Qur’an, Akidah,

${ }^{17}$ Jumal Ahmad "Problematika Pendidikan Agama Islam (PAI) dalam Kurikukulum 2013 dan Revisi 2013", diakses dari https://www.google.com/ search? safe $=$ strict\&hl=in-ID\&soursce $=$ fzoDXOWZLBLQrQ\&q=problematik a+pebdidikan+agama+islam+dalam+kurikulum+2013\&gs_I=mobile-gws-wizserp.3...33i, pada hari Minggu, 2 Desember 2018, pukul 9:20 WIB. Lihat juga Arif Hidayatulloh, Wahidul Anam, Moh. Zainal Fanani, Problematika K13 Dalam Pembelajaran Pai, Edudeena, Vol. 1 No. 2 Juli 2017,|63-73 
Akhlah, Fiqih, Sejarah Peradaban Islam (SPI).

Tabel 1. Contoh Materi Pendidikan Agama Islam SMP/MTS kelas VIII

\begin{tabular}{|c|c|c|}
\hline No. & Ruang Lingkup & Materi Ajar \\
\hline 1. & Al-Qur'an, & $\begin{array}{l}\text { Q.S al-Furqan/25:63, Q.S al-Isra/17:26-27 dan } \\
\text { hadist terkait tentang rendah hati, hemat, dan } \\
\text { hidup sederhana } \\
\text { - Q.S. an-Nahl/16:114 dan hadist terkait tentang } \\
\text { mengkonsusmsi makanan dan minuman yang halal } \\
\text { dan bergizi }\end{array}$ \\
\hline 2. & Akidah & $\begin{array}{l}\text { - Memahami makna beriman kepada kitab-kitab } \\
\text { Allah SWT. } \\
\text { Memahami makna beriman kepada Rasul Allah } \\
\text { SWT. }\end{array}$ \\
\hline 3. & Akhlah & $\begin{array}{l}\text { - Bahaya mengkonsumsi minuman keras, judi, dan } \\
\text { pertengkaran } \\
\text { - Cara menerapkan perilaku jujur dan adil } \\
\text { - Cara berbuat baik, hormat, dan patuh kepada } \\
\text { orang tua dan guru } \\
\text { - Makna perilaku gemar beramal saleh dan berbaik } \\
\text { sangka kepada sesame }\end{array}$ \\
\hline 4. & Fiqih & $\begin{array}{l}\text { - Tata cara Shalat sunah berjamaah dan mufarid } \\
\text { - Tata cara sujud syukur, sujud sahwi, dan sujud } \\
\text { tilawah } \\
\text { - Tat cara puasa wajib dan sunah } \\
\text { - Ketentuan makanan dan minuman yang halal dan } \\
\text { haram berdasarkan al-quran dan hadis }\end{array}$ \\
\hline 5. & $\begin{array}{l}\text { Sejarah Peradaban } \\
\text { Islam (SPI) }\end{array}$ & $\begin{array}{l}\text { - Sejarah pertumbuhan ilmu pengetahuan masa Bani } \\
\text { Umayah } \\
\text { - Sejarah pertumbuhan ilmu pengetahuan masa } \\
\text { Abbasiyah.1 }\end{array}$ \\
\hline
\end{tabular}

\section{G. SISWA LAKI-LAKI DAN PEREMPUAN PRESPEKTIF GENDER}

Kata gender dalam istilah bahasa Indonesia sebenarnya berasal dari Bahasa Inggris yaitu 'gender'. Jika dilihat dalam kamus bahasa Inggris, tidak secara jelas dibedakan pengertian Sex dan gender. Seringkali gender dipersamakan dengan seks (jenis kelamin laki-laki dan perempuan). ${ }^{18}$ Oakley (1972) dalam Sex, Gender and Society meneturkan bahwa gender berarti perbedaan yang bukan biologis dan bukan kodrat Tuhan. Perbedaan biologis dan bukan

${ }^{18}$ Riant Nugroho, Gender Dan Strategi Pengaruh-Utamanya di Indonesia, (Yogyakarta: Pustaka Pelajar, 2011), hlm. 1. 
kodrat Tuhan maka secara permanen berbeda dengan pengertian gender.

Gender merupakan behavioral differences (perbedaan perilaku) antara laki-laki dan perempuan yang dikontruksi secara sosial, yakni perbedaan yang bukan ketentuan Tuhan melainkan diciptakan oleh manusia (bukan kodrat) melalui proses sosial dan kultural yang panjang. Dalam the Cultural Contruction of Sexuality sebagaimana yang diuraikan oleh Caplan (1987) bahwa behavioral differences (perbedaan perilaku) antara perempuan dan laki-laki bukanlah sekedar biologis, namun melalui proses kultural dan sosial. Dengan demikian, gender dapat berubah dari kelas ke kelas, sedangkan jenis kelamin biologis tidak akan berubah. ${ }^{19}$ Suzanne Wiliams, Janet Seed, dan Adelina Mwau dalam the OXFAM Gender Training Manual, mengartikan gender sebagai berikut:

"manusia dilahirkan dan dididik sebagai bayi perempuan dan laki-laki supaya kelak menjadi anak perempuan dan laki-laki serta berlanjut sebagai perempuan dewasa dan laki-laki dewasa. Mereka dididik tentang cara bagaimana bersikap, berprilaku, berperan, dan melakukan pekerjaan yang sepantasnya sebagai perempuan dan laki-laki dewasa. Mereka dididik bagaimana berelasi diantara mereka, sikap-sikap yang dipelajari inilah yang pada akhirnya dapat membentuk identitas diri dan peranan gender mereka dalam masyaratkat."

Sementara itu, Kantor Mentri Negara Pemberdayaan Perempuan Republik Indonesia, mengartikan, gender adalah peran-peran sosial yang dikontruksikan oleh masyarakat, tanggung jawab dan kesempatan laki-laki - perempuan yang diharapkan masyarakat agar peran-peran sosial tersebut dapat dilakukan oleh keduanya (laki-laki dan perempuan). ${ }^{20}$

\section{H. PROBLEMATIKA GENDER DALAM PENDIDIKAN}

Ada beberapa pendapat yang dapat digunakan untuk menjelaskan perbedaan laki-laki dan perempuan. Perempuan dalam hal ini diposisikan sebagai individu yang memiliki prestasi belajar yang lebih baik daripada laki-laki. Mitsos dan Browne dalam Haralambos yang dikutib oleh Zaman Zubaidah, ada bukti yang dapat menjelaskan bahwa perempuan memiliki tingkat prestasi belajar yang lebih baik daripada laki-laki. Menurut mereka perempuan lebih termotivasi dan bekerja lebih rajin daripada laki-laki dalam mengerjakan tugas sekolah.

Di dalam pembahasan klasik mengenai perbedaan laki-laki dan perem-

\footnotetext{
${ }^{19}$ Ibid., hlm. 2.

${ }^{20}$ Ibid., hlm. 4.
} 
puan Eleanor Maccoby dan Carol Jacklin dalam Santrock dikutib dalam Enngar Sarawati menyimpulkan bahwa laki-laki memiliki kemampuan Matematika lebih baik, sedangkan perempuan lebih sukses dalam seni bahasa, pemahaman membaca, dan komunikasi tulis dan lisan sementara laki-laki tampaknya sedikit lebih unggul dalam ilmu Matematika dan pemikiran matematis. $^{21}$

Persoalan-persoalan gender yang kerapkali ditemui dalam dunia pendidikan:

a. Akses, problematika gender dalam pendidikan Yang perama adalah aspek akses, aspek akses adalah fasilitas pendidikan yang sulit diacapai. Misalnya, banyak sekolah dasar di tiap-tiap kecamatan namun untuk jenjang pendidikan selanjutnya seperti SMP dan SMA tidak banyak. Tidak setiap wilayah memiliki sekolah tingkat SMP dan seterusnya hingga banyak siswa yang harus menempuh perjalanan jauh untuk mencapainya. Di lingkungan masyarakat yang masih tradisional, umumnya orang tua segan mengirimkan anak perempuanya ke sekolah yang jauh karena mengkawatirkan kesejahteraan mereka. Oleh sebab itu banyak anak perempuan yang terpaksa tinggal di rumah. Belum lagi beban tugas rumah tangga yang banyak dibebankan pada anak perempuan. Akumulasi faktor ini membuat anak perempuan banyak yang cepat meninggalkan bangku sekolah.

b. Partisipasi, aspek partisipasi tercakup di dalamnya faktor bidang studi dan statistik pendidikan. Dalam masyarakat Indonesia, terdapat sejumlah nilai budaya tradisional yang meletakkan tugas utama perempuan di arena domestik, seringkali anak perempuan agak terhambat untuk memperoleh kesempatan yang luas untuk menjalani pendidikan formal. Sudah sering dikeluhkan bahwa jika sumbersumber pendanaan keluarga terbatas, maka yang harus didahulukan untuk sekolah adalah laki-laki. Hal ini umumnya dikaitkan dengan tugas pria kelak apabila sudah dewasa dan berumah tangga, yaitu bahwa ia harus menjadi kepala rumah tangga dan pencari nafkah.

c. Manfaat dan penguasaan, kenyataan banyaknya angka buta huruf di Indonesia didominasi oleh kaum perempuan. Pendidikan tidak hanya sekedar proses pembelajaran. Tetapi merupakan salah satu

${ }^{21}$ Yuniarti, "Perbandingan Prestasi Belajar Mahasiswa Laki-Laki dan Perempuan Pada Mata Kuliah Matematika 1 Angkatan 2014-2016 Program Studi Pendidikan Guru Madrasah Ibtidaiyah Fakultas Tarbiyah Dan Keguruan Uin Alauddin Makassar", Skripsi, (Makasar: Uin Alauddin, Makasar, 2017), hlm. t.d. 
narasumber bagi segala pengetahuan karenanya ia instrument efektif transfer nilai termasuk nilai yang berkaitan dengan isu gender dengan demikian pendidikan juga sarana sosialisasi kebudayaan yang berlangsung secara formal termasuk disekolah. Perilaku yang tampak dalam kehidupan dalam sekolah interaksi guru-guru, murid-murid, baik didalam maupun diluar kelas pada saat pelajaran berlangsung maupun saat istirahat akan menampakkan kontruksi gender yang terbangun selama ini. Selain itu penataan tempat duduk murid, penataan barisan, pelaksanaan upacara tidak terlepas dari hal tersebut. Siswa laki-laki selalu ditempatkan dalam posisi yang lebih menentukan, misalnya pemimpin organisasi siswa, ketua kelas, dan lainlain. Hal ini menunjukan kesenjangan gender muncul dalam proses pembelajaran disekolah.

Dalam deklarasi hak asasi manusia pasal 26 menyatakan bahwa setiap orang berhak mendapatkan pengajaran, pengajaran harus mempertinggi rasa saling mengerti, saling menerima, serta rasa persahabatan antar semua bangsa. Terkait hal ini sesunguhnya pendidikan bukan hanya dianggap dan dinyatakan sebagai sebuah unsur utama dalam upaya pencerdasan bangsa melainkan juga sebagai produk atau kontruksi social, maka pendidikan juga memiliki andil bagi terbentuknya relasi gender di dalam masyarakat.

Jika sekolah memilih jalan untuk tidak sekedar menjadi pengawet atau penyangga nilai-nilai, tetapi menyeru pikiran yang produktif dengan berkolaborasi dengan kebutuhan zaman, maka menjadi salah satu tugas sekolah untuk tidak membiarkan berlangsungnya ketidakadilan gender yang selama ini terbungkus rapi dalam kesadaran-kesadaran palsu yang berkembang dalam masyarakat. Sebaliknya ia harus bersikap kritis dan mengajak masyarakat sekolah dan masyarakat sekitarnya untuk mengubah atau membongkar kepalsuan-kepalsuan tersebut sekaligus mentransformasikannya menjadi Pratik-praktik yang lenih berpihak kepada keadilan sesama, terutama keadilan bagi kaum perempuan. Guru atau pendidik sebagai pilar harus diupayakan mendapatkan akses terhadap dasar-dasar pengetahuan dan pendidikan gender terlebih dahulu, untuk membukakan pikiran dan nurani akan adanya persoalan ketidakadilan gender.

Pendidikan menuju kesetaraan gender dalam pendidikan merupakan usaha untuk menghentikan bias gender terhadap seluruh aspek kehidupan antara lain dengan cara pemenuhan kebutuhan praktis gender. Adapun strategi utama menuju kesetaraan gender dalam pendidikan yaitu menyediakan akses pendidikan yang bermutu terutama pendidikan dasar seacara merata bagi anak 
laki-laki dan perempuan baik melalui pendidikan persekolahan maupun pendidiakan luar sekolah. Penyedian akses pendidikan kesetaraan bagi penduduk usia dewasa yang tidak dapat mengikuti pendidikan persekolahan. Peningkatan penyediaan pelayanan pendidikan keaksaraan bagi penduduk dewasa terutama perempuan. Peningkatan koordinasi, informasi dan eduksi dalam rangka mengurus utamakan pendidikan berwawasan gender dan pegembangan kelembagaan intitusi pendidikan baik di tingkat pusat maupun daerah mengenai berwawasan gender. ${ }^{22}$

\section{GAMBARAN UMUM SMP 14 NEGERI YOGYAKARTA}

SMP Negeri 14 Yogyakarta beralamatkan di Jl. Tentara pelajar No. 7 Kecamatan Jetis, kota Yogyakarta provinsi Daerah Istimewa Yogyakarta. SMP Negeri 14 sudah terakreditasi A, SMP Negeri 14 Yogyakrta Terletak di Sebelah barat berbatasan dengan Desa Bumijo Kulon, Sebelah timur berbatasan dengan permukiman penduduk dusun Bumijo selanjutnya Sebelah selatan berbatasan dengan Samsat Kota Yogyakarta dan Sebelah utara berbatasan dengan SMP 12 dan BANK BPD. SMP Negeri 14 berdiri di atas lahan seluas $4920 \mathrm{~m} 2$ dan terletak di tempat yang sangat strategis karena terletak di pusat kota sehingga mempermudah aksibilitas.

SMP Negeri 14 Yogyakarta pertama kali berdiri belum memiliki gedung sendiri, tetapi masih menggabung di SMP Negeri 6 Yogyakarta pada tanggal 1 April 1979 dengan murid sebanyak 120 siswa kelas I dengan jumlah guru tetap 6 orang, dan tidak tetap 10 orang bantuan dari SMP Negeri 6 Yogyakarta. Pada tanggal 1 Desember 1981 SMP Negeri 14 Yogyakarta mulai menempati gedung sendiri yang berada di daerah Bumijo, Jetis tepatnya beralamat di Jalan Tentara Pelajar No. 7 dengan bangunan gedung yang masih sederhana.

Kepala Sekolah yang memimpin SMP Negeri 14 Yogyakarta sejak awal berdiri, yaitu sejak ajaran 1980/1981 sampai 1989/1990 dikepalai oleh Drs. Toelardi. Kemudian 1989/1990 sampai 1990/1991 dikepalai oleh Dra. Dhawimah Z. Effendi. Selanjutnya 1990/1991 sampai 1998/1999 dikepalai oleh Drs. Mardiyo. Pada 1998/1999 sampai 2004/2005 dikepalai oleh Dra. D. Kadarini. Pada 2004/2005 sampai 2007/2008 dikepalai oleh Drs. Istiyono.

${ }^{22}$ Yuliana Krismonni, “Gender dalam Pendidikan” di akses dari https://medium. com/@monibeltim/gender-dalam-pendidikan-dd6ca967be24, pada hari Kamis, 1 November 2018, pukul O8.34 WIB. Lihat juga Aris Try Andreas Putra, Peran Gender dalam Pendidikan Islam Jurnal Pendidikan Islam, Volume III, Nomor 2, Desember 2014, 327-343 
Tahun 2007/2008 sampai 2009/2010 dikepalai oleh Drs. Joko Waskito. Pada 2009/2010 sampai 2010 /2011 dikepalai oleh Drs. Paidjan. Pada 2010/2011 sampai 2014/2015 dikepalai oleh Tyas Ismullah, S.Pd. Pada 2014/2015 sampai 2017/2018 dikepalai Drs.Marsono, M.M. Selanjutnya 2017/2019 sampai 2022/2023 dikepalai oleh Drs. Siswanto. ${ }^{23}$

SMP Negeri 14 Yogykarta memiliki guru sebanyak 32 Guru PNS, 1 Honorer, Sedangkan Staff SMP Negeri 14 Yogyakarta sebanyak 7 orang. SMP Negeri 14 Yogyakarta secara keseluruhan memiliki siswa sebanyak 403 siswa, untuk kelas VII A,B,C dan D, seluruhnya terdiri dari 139 siswa, diantara 139 siswa tersebut terdapat 15 anak non Islam selebihnya Islam baik lakilaki maupun perempuan, kemudian kelas VIII A,B,C dan D, terdiri dari 130 siswa, diantara 130 siswa tersebut terdapat 19 siswa non Islam selebihnya Islam semua baik laki-laki maupuan perempuan dan jumlah kelas IX keseluruhan berjumlah 134 diantara 134 siswa terdapat 14 siswa Non-Islam selebihnya Islam semua.

Pada penelitian ini sebagai subjek penelitian adalah keseluruhan kelas VIII A,B,C, dan D baik laki-laki maupun perempuan khususnya yang beragama Islam, untuk kelas VIII Siswa laki-laki dan perempuan secara keseluruhan berjumlah sebanyak 111 siswa dengan spesifikasi kelas VIII A terdiri dari 17 siswa laki-laki dan 16 siswa perempuan, kelas VIII B siswa laki-laki terdiri dari 16, siswa perempuan terdiri dari 16 siswa selanjutnya kelas VIII C terdiri dari 9 siswa laki-laki dan 10 siswa perempuan kemudian kelas VIII D terdiri dari 16 siswa laki-laki dan 11 siswa perempuan.

Visi Sekolah Menengah Pertama (SMP) Negeri 14 Yogyakarta adalah Generasi Berprestasi, Handal Berpribadi dan Berwawasan Teknologi. Dengan visi tersebut SMP 14 Yogyakarta bertujuan adalah sebagai berikut: (1) terwujudnya pengembangan kurikulum yang adaptif dan proaktif (2) terwujudnya proses pembelajaran yang efktif dan efisien, (3) terwujudnya lulusan yang cerdas dan kompetitif, (4) terwujudnya SDM yang memiliki kemampuan dan kesanggupan kerja yang tinggi, (5) terwujudnya sarana dan prasarana pendidikan, (6) terwujudnya manajemen sekolah yang tangguh, (7) terwujudnya penggalangan biaya pendidikan yang memadai, dan (8) terwujudnya standar penilaian prestasi akademik dan non akademik. ${ }^{24}$

\footnotetext{
${ }^{23}$ Observasi dan wawancara kepada Bapak Eko ariyanto BS tanggal 31 Januari jam $9: 10$

${ }^{24}$ Hasil buku dokumentasi kesiswaan dan wawancara kepada bapak R.hargo budisantoso,S.Pd tanngal 30 Januari 2018, jam 9:30.
} 


\section{J. HASIL PENELITIAN}

Untuk mengetahui lebih jelas mengenai hasil penelitian tentang Prestasi Belajar Pendidikan Agama Islam dan Budi Pekerti siswa di SMP Negeri 14 Yogyakarta tahun ajaran 2018/2019 dalam perpektif gender dapat diuraikan sebagai berikut:

\section{Analisis data Deskriptif}

Analisis Data Deskriptif digunakan untuk memberikan deskripsi mengenai subjek penelitian berdasarkan data dari variable yang diperoleh dari kelompok subjek dan tidak dimaksudkan untuk mengujian hipotesis. sekalipun penelitian yang dilakukan bersifat inferensial, sajian keadaan subjek dan data penelitian secara deskriptif tetap perlu diketenggahkan lebih dahulu sebelum pengujian hipotesis dilakukan. Selanjutnya untuk menentukan:

a. Rata-rata (Mean),

b. Standar Deviasi, dan

c. Total range $(\mathrm{R})$ pervariabel antara siswa laki-laki dan perempuan Kelas VIII A,B,C dan D dengan bantuan program IMB SPSS versi 20.0 sebagai berikut:

Tabel 1. Hasil Uji Mean, Standar deviasi, dan Total Rang IMB SPSS Versi 20.0 .

\section{Descriptive Statistics}

\begin{tabular}{|l|c|c|c|c|c|c|c|}
\hline & N & Range & Minimum & Maximum & Mean & $\begin{array}{c}\text { Std. } \\
\text { Deviation }\end{array}$ & Variance \\
\hline $\begin{array}{l}\text { Hasil_Prestasi_ } \\
\text { laki-laki }\end{array}$ & 53 & 27 & 68 & 95 & 81.51 & 6.863 & 47.101 \\
\hline $\begin{array}{l}\text { Hasil_Prestasi_ } \\
\text { Perempuan }\end{array}$ & 53 & 28 & 71 & 99 & 84.57 & 7.324 & 53.635 \\
\hline $\begin{array}{l}\text { Valid N } \\
\text { (listwise) }\end{array}$ & 53 & & & & & & \\
\hline
\end{tabular}

Dari tabel di atas dapat diketahui jumlah data antara siswa laki-laki dan perempuan berjumlah sama yaitu 53 siswa, 53 siswa merupakan jumlah sampel yang sudah disamaratakan antara siswa laki-laki dan perempuan mengigat jumlah perempuan hanya terdiri dari 54 siswa dan diantara 54 tersebut ada 1 siswa pindahan yang tidak mengikuti Penilaian Tenggah semester sehingga peneliti tidak memasukkanya dalam sampel penelitian dan menjadi 53 siswa perempuan selanjutnya untuk jumlah laki-laki terdiri dari 58 siswa kemu- 
dian untuk menyamakan jumlah siswa perempuan peneliti mengurangai 5 siswa laki-laki menjadi 53 siswa mengunakan metode sample random dengan bantuan Aplikasi IMB SPSS Versi 20.0

Pada tabel di atas rata-rata nilai Pendidikan Agama Islam siswa lakilaki 81,51, standar deviasi 6,863 Total Range 27, nilai terkecil 68 dan nilai tertinggi 95, sedangkan nilai rata-rata Pendidikan Agama Islam perempuan 84,57 dengan standar deviasi 7.324, total range 28 , nilai terkecil 71 dan nilai tertinggi 99.

Pengkategorian nilai siswa laki-laki dan perempuan sebagai berikut:

1) Frekuensi Nilai Siswa laki-laki

Tabel 2. Uji Frekuensi Nilai Siswa Laki-laki

Hasil_Prestasi_Laki_Laki

\begin{tabular}{|c|c|c|c|c|c|}
\hline & Frequency & Percent & Valid Percent & Cumulative Percent \\
\hline \multirow{21}{*}{ Valid } & 68 & 1 & 1.9 & 1.9 & 1.9 \\
\hline & 70 & 1 & 1.9 & 1.9 & 3.8 \\
\hline & 71 & 1 & 1.9 & 1.9 & 5.7 \\
\hline & 73 & 2 & 3.8 & 3.8 & 9.4 \\
\hline & 74 & 2 & 3.8 & 3.8 & 13.2 \\
\hline & 75 & 7 & 13.2 & 13.2 & 26.4 \\
\hline & 76 & 4 & 7.5 & 7.5 & 34.0 \\
\hline & 77 & 2 & 3.8 & 3.8 & 37.7 \\
\hline & 80 & 4 & 7.5 & 7.5 & 45.3 \\
\hline & 81 & 4 & 7.5 & 7.5 & 52.8 \\
\hline & 82 & 4 & 7.5 & 7.5 & 60.4 \\
\hline & 85 & 2 & 3.8 & 3.8 & 64.2 \\
\hline & 86 & 4 & 7.5 & 7.5 & 71.7 \\
\hline & 87 & 6 & 11.3 & 11.3 & 83.0 \\
\hline & 88 & 1 & 1.9 & 1.9 & 84.9 \\
\hline & 89 & 2 & 3.8 & 3.8 & 88.7 \\
\hline & 90 & 1 & 1.9 & 1.9 & 90.6 \\
\hline & 93 & 2 & 3.8 & 3.8 & 94.3 \\
\hline & 94 & 1 & 1.9 & 1.9 & 96.2 \\
\hline & 95 & 2 & 3.8 & 3.8 & 100.0 \\
\hline & Total & 53 & 100.0 & 100.0 & \\
\hline
\end{tabular}




\begin{tabular}{|c|c|c|c|c|c|}
\hline \multicolumn{2}{|c|}{} & Frequency & Percent & Valid Percent & Cumulative Percent \\
\hline \multirow{4}{*}{ Valid } & $93-100$ & 5 & 9.4 & 9.4 & 9.4 \\
\cline { 2 - 6 } & $84-92$ & 16 & 30.2 & 30.2 & 39.6 \\
\cline { 2 - 6 } & $75-83$ & 25 & 47.2 & 47.2 & 86.8 \\
\cline { 2 - 6 } & $0-74$ & 7 & 13.2 & 13.2 & 100.0 \\
\cline { 2 - 6 } & Total & 53 & 100.0 & 100.0 & \\
\hline
\end{tabular}

Gambar 1. Histogram Frekuensi nilai laki-laki

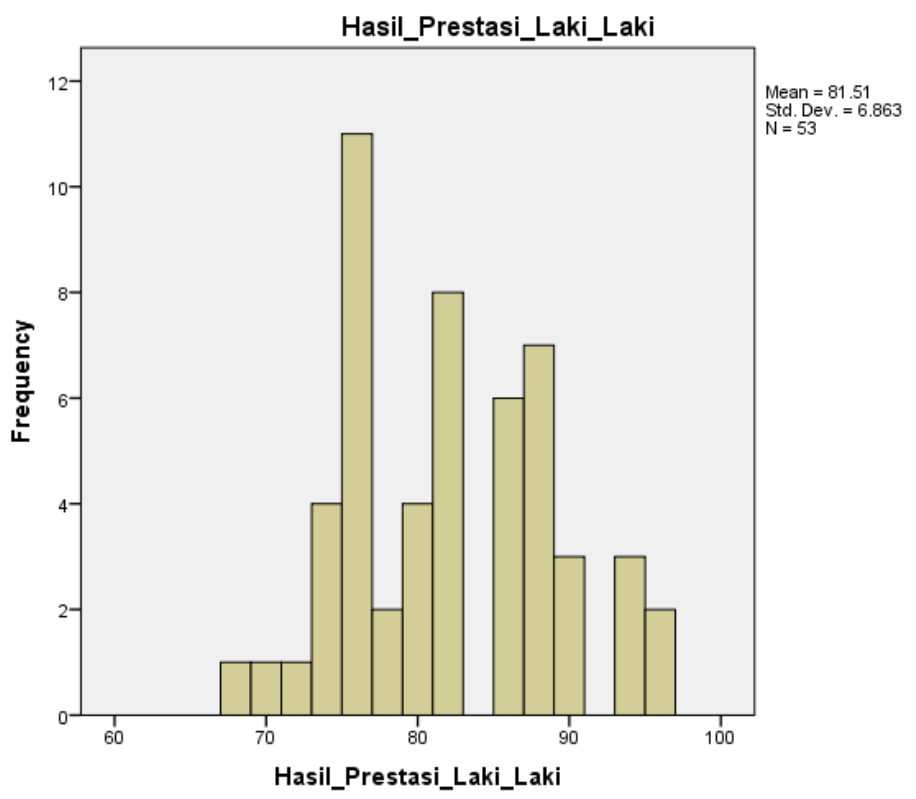

Dari tabel di atas dapat diketahui jumlah sampel sebanyak 53 siswa lakilaki, rata-rata nilai sebesar 81,51 dengan standar deviasi 6,863 dan berada dalam kategori cukup baik, yaitu antara skor 75 - 83 dari responden sebanyak 25 siswa, atau $47,2 \%$ berada dalam kategori cukup baik (C) dari 53 siswa lakilaki. Kualifikasi variabel, dapat lebih jelas dengan melihat tabel 3 berikut: 
Tabel 3. Keterangan kategori dan presentase nilai laki-laki

\begin{tabular}{|c|c|c|c|c|}
\hline Skor & Nilai & Kategori & Jumlah & Presentase (\%) \\
\hline $93-100$ & A & Sangat baik & 5 & $9,4 \%$ \\
\hline $84-92$ & B & Baik & 16 & $30,2 \%$ \\
\hline $75-83$ & $\mathrm{C}$ & Cukup baik & 25 & $47,2 \%$ \\
\hline $0-74$ & $\mathrm{D}$ & Perlu bimbingan & 7 & $13,2 \%$ \\
\hline \multicolumn{3}{|c|}{ Jumlah } & 53 & $100 \%$ \\
\hline
\end{tabular}

2) Frekuensi nilai Siswa Perempuan

Tabel 4. Uji Frekuensi siswa Perempuan

Hasil_Prestasi_Perempuan

\begin{tabular}{|c|l|l|l|l|}
\hline & Frequency & Percent & Valid Percent & Cumulative Percent \\
\hline 71 & 3 & 5.7 & 5.7 & 5.7 \\
73 & 2 & 3.8 & 3.8 & 9.4 \\
74 & 1 & 1.9 & 1.9 & 11.3 \\
75 & 2 & 3.8 & 3.8 & 15.1 \\
76 & 1 & 1.9 & 1.9 & 17.0 \\
79 & 2 & 3.8 & 3.8 & 20.8 \\
80 & 2 & 3.8 & 3.8 & 24.5 \\
81 & 7 & 13.2 & 13.2 & 37.7 \\
82 & 1 & 1.9 & 1.9 & 39.6 \\
83 & 5 & 9.4 & 9.4 & 49.1 \\
85 & 3 & 5.7 & 5.7 & 54.7 \\
86 & 3 & 5.7 & 5.7 & 60.4 \\
87 & 2 & 3.8 & 3.8 & 64.2 \\
88 & 5 & 9.4 & 9.4 & 73.6 \\
89 & 1 & 1.9 & 1.9 & 75.5 \\
90 & 1 & 1.9 & 1.9 & 77.4 \\
92 & 3 & 5.7 & 5.7 & 83.0 \\
93 & 1 & 1.9 & 1.9 & 84.9 \\
94 & 3 & 5.7 & 5.7 & 90.6 \\
95 & 1 & 1.9 & 1.9 & 92.5 \\
96 & 2 & 3.8 & 3.8 & 96.2 \\
98 & 1 & 1.9 & 1.9 & 98.1 \\
99 & 1 & 1.9 & 1.9 & 100.0 \\
Total & 53 & 100.0 & 100.0 & \\
\hline
\end{tabular}




\begin{tabular}{|c|c|c|c|c|c|}
\hline \multicolumn{6}{|c|}{ Interval } \\
\hline & & Frequency & Percent & Valid Percent & Cumulative Percent \\
\hline \multirow{5}{*}{ Valid } & $93-100$ & 9 & 17.0 & 17.0 & 17.0 \\
\hline & $84-92$ & 18 & 34.0 & 34.0 & 50.9 \\
\hline & $75-83$ & 20 & 37.7 & 37.7 & 88.7 \\
\hline & 5 & 6 & 11.3 & 11.3 & 100.0 \\
\hline & Total & 53 & 100.0 & 100.0 & \\
\hline
\end{tabular}

Gambar 2. Histogram Hasil Prestasi Perempuan

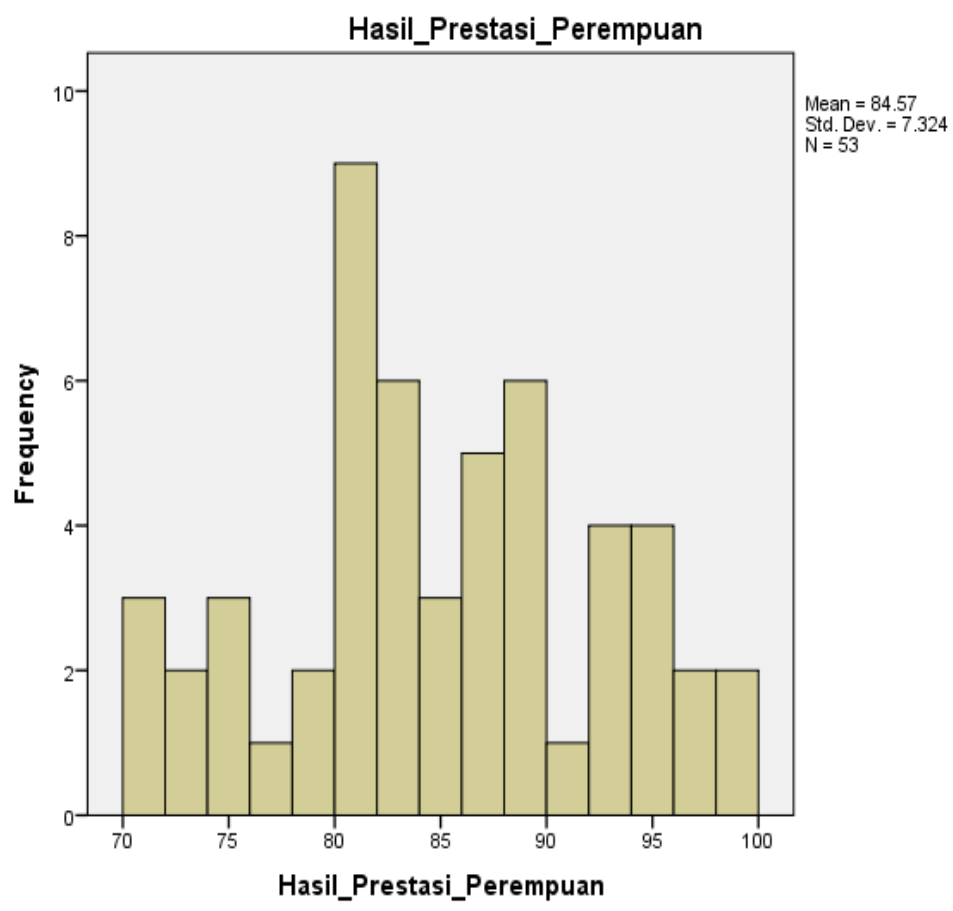

Dari tabel diatas dapat diketahui jumlah sampel sebanyak 53 siswa Perempuan, rata-rata nilai sebesar 84,57 dengan standar deviasi 7,324, dan berada dalam kategori baik, yaitu antara skor 75 - 83 dari responden sebanyak 20 siswa, atau terdapat $37,7 \%$ kategori cukup baik dari 53 siswa perempuan.

Kualifikasi variabel, dapat lebih jelas dengan melihat tabel berikut: 
Tabel 5. Keterangan Frekuensi dan Presentase nilai siswa perempuan

\begin{tabular}{|l|l|l|l|l|}
\hline \multicolumn{1}{|c|}{ Skor } & \multicolumn{1}{c|}{ Nilai } & \multicolumn{1}{c|}{ Kategori } & \multicolumn{1}{c|}{ Jumlah } & \multicolumn{1}{c|}{ Persentase } \\
\hline $93-100$ & A & Sangat baik & 9 & $17,0 \%$ \\
\hline $84-92$ & B & Baik & 18 & $34,0 \%$ \\
\hline $75-83$ & C & Cukup baik & 20 & $37,7 \%$ \\
\hline $0-74$ & D & Perlu bimbingan & 6 & $11,3 \%$ \\
\hline Jumlah & & 53 & $100 \%$ \\
\hline
\end{tabular}

\section{Analisis Data Inferensial}

Dikarenakan penelitian ini menggunakan teknis analisis parametris, maka data dari setiap variabel yang akan dianalisis harus berdistribusi normal dan homogen atau berasal dari varian yang sama. Data yang digunakan untuk uji normalitas dan homogenitas ini adalah data hasil Penilaian Akhir Penilaian Tenggah Semester (PTS) dan Penilaian Akhir Semester(PAS) Siswa laki-laki dan perempuan SMP Negeri 14 Yogyakarta tahun ajaran 2018/2019 yang sudah dikonvensianalkan yang artinya nilai sudah mencakup ranah, kognitif, afektif, dan psikomotorik.

\section{a. Uji Normalitas}

Uji normalitas digunakan untuk mengetahui kenormalan data yang digunakan dalam penelitian. Untuk mendeteksi apakah data-data yang diuji berdistribusi normal atau tidak yaitu dengan mengunakan uji Kolmogorov smirnov, karena sampel $<50$, jika sampel $<50$ maka mengunakan Shapiro wilk dari variabel penelitian. Kriteria bahwa data berdistribusi normal apabila;

1) Nilai signifikan $>5 \%$ atau 0.05 , maka data berdistribusi normal

2) Nilai signifikansi $<5 \%$ atau 0.05 , maka data berdistribusi tidak normal

Berikut hasil uji Normalitas yang penelitian lakukan dengan bantuan IBM SPSS versi 20.0:

Tabel 6. Hasil Uji Normalitas IMB SPSS Versi 20.0

\section{One-Sample Kolmogorov-Smirnov Test}

\begin{tabular}{|ll|l|l|}
\hline & & $\begin{array}{l}\text { Hasil_Prestasi_ } \\
\text { laki_laki }\end{array}$ & $\begin{array}{l}\text { Hasil_Prestasi__ } \\
\text { Perempuan }\end{array}$ \\
\hline N & & 53 & 53 \\
\multirow{2}{*}{ Normal Parametersa,b } & Mean & 81.51 & 84.57 \\
& Std. Deviation & 6.863 & 7.324
\end{tabular}




\begin{tabular}{|ll|l|l|} 
& Absolute & .129 & .075 \\
Most Extreme & Positive & .129 & .075 \\
Differences & Negative & -.102 & -.071 \\
Kolmogorov-Smirnov Z & & .936 & .548 \\
Asymp. Sig. (2-tailed) & & .345 & .925 \\
\hline
\end{tabular}

a. Test distribution is Normal.

b. Calculated from data.

Dari hasil analisis tabel di atas dapat diketahui nilai signifikan dari variabel "nilai laki-laki adalah 0.345 , dan nilai signifikansi dari variabel "nilai siswa perempuan" adalah 0.925 , dimana nilai signifikansi dari kedua tabel adalah $>0,05$ (5\%) maka dinyatakan Normal.

\section{b. Uji Homoginitas}

Uji Homoginitas digunakan untuk menunjukan bahwa kondisi sampel yang diambil adalah berasal dari kondisi yang sama atau homogen. Uji homogen sama atau tidaknya adalah dengan melihat nilai signifikansi, jika nilai signifikansi $<5 \%$ atau 0.05 , maka kedua variabel tersebut tidak berasal dari kondisi yang sama atau tidak homogen. Dan jika nilai signifikan $>5 \%$ atau 0,05 maka variabel berasal dari kondisi yang sama atau Homogen. Berikut uji homogenitas dengan bantuan program IMB SPSS 20.0:

Tabel 7. Hasil uji Homogenitas IMB SPSS Versi 20.0

\section{Test of Homogeneity of Variances}

Hasil_Prestasi_laki_lak

\begin{tabular}{|l|l|l|l|}
\hline Levene Statistic & $\mathrm{df1}$ & $\mathrm{df2}$ & Sig. \\
\hline .072 & 1 & 104 & .788 \\
\hline
\end{tabular}

Dari tabel di atas dapat dilihat nilai signifikannya adalah 0,788, yang artinya $>5 \%$ atau 0,05 . Maka data variabel penelitian nilai prestasi laki-laki dan perempuan berasal dari kondisi yang sama atau homogen.

\section{c. Analisis Uji Hipotesis}

Analisis ini digunakan untuk menguji hipotess yang diajukan, yaitu untuk menguji perbedaan prestasi antara siswa laki-laki dan perempuan . adapun uji hipotesis dalam peneltian ini adalah mengunakan uji sampel independent t-test, dikarenakan variabel dalam penelitian ini adalah 2 variabel bebas dan tidak berkolerasi. 
Hipotesis yang diajukan dalam penelitian ini ada 2 yaitu Ho dan $\mathrm{Ha}$. $\mathrm{Ha}$ dalam penelitian ini adalah:

$\mathrm{Ha}$ : Terdapat perbedaan yang positif dan signifikan antara siswa laki-laki dan perempuan terhadap prestasi belajar pendidikan Agam Islam dan Budi pekerti siswa kelas VIIIA SMP Negeri 14 Yogyakarta tahun ajaran 2018/2019. Sedangkan HO nya,

Ho : Tidak ada perbedaan yang positif dan signifikan antara siswa lakilaki dan perempuan terhadap prestasi belajar pendidikan Agam Islam dan Budi pekerti siswa kelas VIII SMP Negeri 14 Yogyakarta tahun ajaran 2018/2019.

\section{d. Uji t}

Untuk mengetahui jawaban dari Hipotesis di atas, peneliti mengunkan teknik analisis kolerasi $T$ test independent atau uji $T$ dengan Program IMB SPSS Versi 20.0, dengan perhitungan sebagai berikut:

Tabel 8. Hasil Uji T test Independent IMB SPSS Versi 20.0

\section{Group Statistics}

\begin{tabular}{|l|l|c|l|l|l|}
\hline & Jenis_kelamin & N & Mean & Std. Deviation & $\begin{array}{c}\text { Std. Error } \\
\text { Mean }\end{array}$ \\
\hline $\begin{array}{l}\text { Hasil_Prestasi__laki } \\
\text { laki_laki }\end{array}$ & laki-laki & 53 & 81.51 & 6.863 & .943 \\
\cline { 2 - 6 } & Perempuan & 53 & 84.57 & 7.324 & 1.006 \\
\hline
\end{tabular}

\section{Independent Samples Test}

\begin{tabular}{|c|c|c|c|c|c|c|c|c|c|c|}
\hline & \multicolumn{2}{|c|}{\begin{tabular}{|l|} 
Levene's Test \\
for Equality \\
of Variances \\
\end{tabular}} & \multicolumn{7}{|c|}{ t-test for Equality of Means } \\
\hline & & \multirow[t]{2}{*}{$\mathrm{F}$} & \multirow[t]{2}{*}{ Sig. } & \multirow[t]{2}{*}{$\mathrm{T}$} & \multirow[t]{2}{*}{ Df } & \multirow[t]{2}{*}{$\begin{array}{l}\text { Sig. } \\
\text { (2-tailed) }\end{array}$} & \multirow[t]{2}{*}{$\begin{array}{l}\text { Mean } \\
\text { Difference }\end{array}$} & \multirow[t]{2}{*}{$\begin{array}{l}\text { Std. Error } \\
\text { Difference }\end{array}$} & \multicolumn{2}{|c|}{$\begin{array}{l}\text { 95\% Confidence } \\
\text { Interval of the } \\
\text { Difference }\end{array}$} \\
\hline & & & & & & & & & Lower & Upper \\
\hline \multirow{2}{*}{$\begin{array}{l}\text { Hasil_ } \\
\text { Prestasi_ } \\
\text { laki_laki }\end{array}$} & $\begin{array}{l}\text { Equal } \\
\text { variances } \\
\text { assumed }\end{array}$ & .072 & .788 & -2.217 & 104 & .029 & -3.057 & 1.379 & -5.791 & -.323 \\
\hline & $\begin{array}{l}\text { Equal } \\
\text { variances } \\
\text { not } \\
\text { assumed }\end{array}$ & & & -2.217 & 103.564 & .029 & -3.057 & 1.379 & -5.791 & -.323 \\
\hline
\end{tabular}


Dari Tabel Uji t di atas, diketahui:

Tabel 9. Keterangan Uji T test Independent

\begin{tabular}{|l|l|l|l|l|l|}
\hline Variabel & Kelompok & & Mean & Sign & Keterangan \\
\hline $\begin{array}{l}\text { Perbandingan } \\
\text { Prestasi Belajar }\end{array}$ & Siswa laki-laki & & 81,51 & \multirow{2}{*}{0.29} & Signifikan \\
\cline { 2 - 4 } & $\begin{array}{l}\text { Siswa } \\
\text { Perempuan }\end{array}$ & & 84,57 & 0.29 & \\
\hline
\end{tabular}

Dari tabel di atas diketahui bahwa nilai sign 0,29 karena sign $>0.05$ atau 5\% maka Ha ditolak dan Ho diterima, artinya tidak terdapat perbedaan yang positif dan signifikan antara siswa laki-laki dan perempuan terhadap prestasi belajar pendidikan Agama Islam dan Budi Pekerti siswa kelas VIII SMP Negeri 14 Yogyakarta tahun ajaran 2018/2019. Hasil penelitian menunjukan bahwa nilai mean untuk skor prestasi belajar laki-laki sebesar 81,51 dan nilai mean skor prestasi belajar perempuan sebesar 84,57.

\section{K. PEMBAHASAN}

Hasil $t$-test independent perbandingan prestasi belajar pada siswa laki-laki kelas VIII yang diambil dari 53 responden skor tertinggi yang didapat adalah 95 dan skor terendah 68. Dari data perhitungan rata-rata dan standar deviasi diketahui bahwa prestasi belajar siswa laki-laki kelas VIII sebesar 81,51 dengan standar deviasi 6,863 dan total rang 27. Mayoritas siswa laki-laki mendapatkan nilai dengan ketogori cukup baik antara 75 - 83, yaitu 25 siswa, atau terdapat 47,2\% dalam kategori cukup baik dari 53 siswa laki-laki.

Sementara Prestasi belajar siswa Perempuan yang diambil dari 53 Responden, skor tertinggi 99 dan sekor terendahnya adalah 71. Dari perhitungan rata-rata dan standar deviasi, diketahui bahwa prestasi belajar Pendidikan Agama Islam Perempuan rata-rata sebesar 85,57 dengan standar deviasi 7,324 , dan total range 28 , dalam ketogori cukup baik antara 75-83 dari responden 20 siswa, atau terdapat 37,7\% kategori cukup baik dari 53 siswa perempuan.

Berdasarkan pengujian hipotesis di atas diketahui bahwa nilai sign (2 tailed) $0,29>0,5$ atau 5\% maka Ha ditolak dan Ho diterima, yang artinya tidak terdapat perbedaan yang positif dan signifikan antara siswa laki-laki dan perempuan terhadap prestasi belajar Pendidikan Agama Islam dan Budi Pekerti siswa kelas VIII SMP Negeri 14 Yogyakarta tahun ajaran 2018/2019. 


\section{KESIMPULAN}

Berdasarkan urain tersebut di atas dapat disimpulkan sebagai berikut: prestasi belajar siswa laki-laki Pendidikan Agama Islam memiliki rata-rata nilai 81,51 dengan standar deviasi 6,863, total Range 27. Nilai terendah siswa laki-laki 68 dan nilai tertinggi 95. Mayoritas nilai siswa laki-laki masuk dalam ketogori cukup baik atau nilai 75-83 yaitu 25 siswa atau 47,2\% siswa laki-laki dari 53 siswa laki-laki. Sedangkan prestasi belajar Pendidikan Agama Islam, siswa perempuan memiliki rata-rata nilai 85,57 dengan standar deviasi 7,324, total range 28, nilai terendah 71 dan nilai tertinggi 99. Mayoritas siswa perempuan juga mendapatkan nilai dengan kategori cukup baik (mendapatkan skor 75-83), yaitu sebanyak 20 siswa, atau terdapat 37,7\% siswa 53 siswa perempuan. Jadi Prestasi siswa laki-laki dan perempuan kelas VIII SMP Negeri 14 Yogyakarta tahun ajaran 2018/2019 tidak terdapat perbedaan yang positif dan signifikan, karena nilai sig ( 2 tailed) 0,29>0,05. 


\section{DAFTAR PUSTAKA}

Ahmad Syafi'i dkk. "Studi tentang Prestasi Belajar Siswa dalam Berbagai Aspek dan Faktor yang Mempengaruhi." Jurnal Komunikasi Pendidikan 2, no. 2 (Juli 2018).

Arikunto, Suharsimi. Prosedur Penelitian Suatu Pendekatan Praktik. Jakarta: Rineka Cipta, 2010.

Artaria, Myrtati D. "Perbedaan Antara Laki-laki Dan Perempuan: Penelitian Antropometris Pada Anak-Anak Umur 6-19 Tahun." Jurnal Masyarakat Kebudayaan Dan Politik 2, no. 4 (n.d.): 343-349.

Azwar, Saifuddin. Metode Penelitian. Yogyakarta: Pustaka Belajar, 2015.

Fahrudin, Hasan Asari, Siti Halimah. "Implementasi Kurikulum 2013 Pendidikan Agama Islam Dan Budi Pekerti Dalam Menanamkan Akhlakul Karimah Siswa." Edu Religia 1, no. 4 (Oktober-Desember 2017): 516-531.

Gadis Arivia. Feminisme; Sebuah Kata Hati. Jakarta: Penerbit Buku Kompas, 2006.

Hidayah, Ulfah. "Perbandingan Akhlak Antara Siswa Program Tahfidz

Dengan Non Tahfidz kelas VIII di MTS Ali Maksum Krapyak Yogyakarta Tahun Ajaran 2017/2018." Skripsi (Universitas Alma Ata Yogyakarta), 2018.

Kementerian dan Kebudayaan. Model Silabus Mata Pelajaran Sekolah Menengah Pertama/Madrasah Tsanawiyah. Jakarta: Kementerian Pendidikan dan Kebudayaan, 2017.

Kitab Musnad Abu Hanifah, Jawami'u al Kalim 4.5. n.d.

Machfoedz, Irham. Metode Penelitian kuantitatif dan kualitatif. Yogyakarta:

Fitramaya, 2016.

Moh Zaiful Rasyid dkk. Prestasi Belajar. Malang: Literasi Nusantara, 2019.

Muafiah, Evi. "Pendidikan Islam Berperspektif Gender." Jurnal Tadris 5, no. 2 (2010): 194-196.

Nugroho, Riant. Gender Dan Strategi Pengaruh-Utamanya di Indonesia. Yogyakarta: Pustaka Pelajar, 2011.

Permendikbud no 23 tahun 2016. Tentang Standar Penilaian Pendidikan Dasar dan Menengah. Jakarta: Kermendikbud, 2016.

Putra, Aris Try Andreas. "Peran Gender dalam Pendidikan Islam." Jurnal Pendidikan Islam III, no. 2 (Desember 2014): 327-343.

Rita Eka Izzaty dkk. "Prediktor Prestasi Belajar Siswa Kelas 1 Sekolah Dasar." Jurnal Psikologi 44, no. 2 (2017). 
Sugiyono. Metode Penelitian Kuantitatif, Kualitatif Dan $R$ \& D. Bandung: Alfabeta, 2011.

-. Statistik Untuk Penelitian. Bandung: Alfabeta, 2007.

Sukmadinata, Nana Syaodih. Metode Penelitian Pendidikan. Bandung: Remaja Rosdakarya, 2011.

Syah, Muhibbin. Psikologi Pendidikan Dengan Pendekatan Baru. Bandung: PT Raja Grafindo Persada, 2008.

Yuniarti. "Perbandingan Prestasi Belajar Mahasiswa Laki-Laki dan Perempuan Pada Mata Kuliah Matematika 1 Angkatan 2014-2016 Program Studi Pendidikan Guru Madrasah Ibtidaiyah Fakultas Tarbiyah Dan Keguruan Uin Alauddin Makassar." Skripsi (Uin Alaudin Makasar), 2017.

Yuniarti, Rohma Dwi. "Pengaruh Sikap dan Gender Terhadap Prestasi Belajar Bahasa Indonesia Pada Siswa SMP Negeri Kelas VII Di Kecamatan Sleman Yogyakarta." Skripsi ( Universitas Negri Yogyakarta), 2013. 